\title{
APPLICATION OF ALGORITHM OF DISCIPLINE D2 OF G8D METHOD IN SOLVING SELECTED PROBLEMS OF QUALITY CONTROL MANAGEMENT
}

doi: $\quad 10.2478 /$ czoto-2019-0076

Date of submission of the article to the Editor: 30/11/2018

Date of acceptance of the article by the Editor: 16/01/2019

\author{
Joanna Cyganiuk ${ }^{1}$ - orcid id: 0000-0002-7279-0692 \\ Adam Idzikowski ${ }^{2}$ orcid id: 0000-0003-1178-8721 \\ Piotr Kuryło ${ }^{3}$ - orcid id: 0000-0001-9820-1254 \\ Andrzej Tomporowski ${ }^{4}$ - orcid id: 0000-0002-9860-8748 \\ Weronika Kruszelnicka ${ }^{5}$ - orcid id: 0000-0002-9909-5112 \\ ${ }^{1,3}$ University of Zielona Gora, Poland \\ ${ }^{2}$ Czestochowa University of Technology, Poland, adam.idzikowski@wz.pcz.pl \\ ${ }^{4,5}$ UTP University of Science and Technology, Poland
}

\begin{abstract}
The G8D method is a universal method for solving problems arising in production processes, also used in optimisation of these processes. The method allows the detection and elimination of any drawbacks occurring in manufacturing processes and ensuring the safety of these processes.

In the article, the authors have presented one of the sensitive and critical disciplines of the G8D problem solving method in production processes, i.e. discipline D2 "problem description". The authors have presented the algorithm of procedure in the discipline D2 as well as the quality management tools that can be used to correctly "describe the problem". The authors have also discussed the procedure for the discipline D2 in the "problem description" for the case of the projection welding of a nut.
\end{abstract}

Keywords: G8D method, problem description, quality management, production process, safety

\section{INTRODUCTION}

The G8D method (Global 8 Disciplines) is a method that allows solving problems reported by clients (complaints) when the cause of the problem lies with the producer who delivered the defective product (Grecu, Belu, Misztal, 2015).

The complaints mainly concern defects and incorrectly performed elements of finished or semi-finished products, showing inconsistencies with the technical documentation (Sarkar, Rajagopalan, 2018).

This method, although mainly used in the automotive industry, is now also used in other areas such as logistics, design, warehousing, etc. 
The G8D method consists of eight steps, called disciplines (Ramachandran et all, 2013). Thanks to the eight disciplines, the method allows to analyse the reason for the complaint, from acknowledging the problem, through its description to the corrective actions, which eliminate the cause of the defect occurrence. The G8D method requires cooperation of an expert group, whose task is to recognize the cause (or causes) of defects and to propose methods for its (their) elimination. The group of experts is required, apart from proposing methods of problem solving, to have in mind the good interest of the company, thus, to take into account not only technical but also economic aspects. Experts are bound to complete a report on individual steps of the G8D. The correct and reliable proceeding and completion of the subsequent points of the procedure ensures the solution of the problem, the optimisation of the defective process and drawing conclusions for the future. Thanks to the conclusions of the G8D report, it is possible to modernize not only a defective production process, but also similar processes that may have, for example, a similar hardware structure which proved to be unreliable (which had already been shown in a G8D report of a defective process). G8D therefore provides not only the possibility of the production processes optimization, but also increases the safety of these processes.

The G8D method uses quality management tools that help discover the source of the problem, and therefore the causes of defects in production processes.

One of the important disciplines of the G8D method is the so-called D2 discipline, i.e. a "problem description" being an important part of the G8D report (Celmerowski 2007, Babica \& Pająk, 2006). The correctly performed description of the problem conditions the effectiveness of conclusion drawing in the G8D method. An incorrect, laconic description may contribute to the erroneous recognition of the cause (source) of defects, and thus to wrong conclusions and focusing on a process which is not the source of the problem.

\section{ALGORITHM OF CONDUCT IN DISCIPLINE D2 IN G8D METHOD}

Discipline D2 is a sensitive stage in the G8D method, and although it may seem that it is an insignificant discipline, it requires significant involvement.

A thoroughly performed description of the problem allows, even at the initial stage, to eliminate some of the potential causes, so that in subsequent disciplines it is possible to focus on a smaller number of them, or if necessary, set up another group of experts analyzing separately the potential causes in a separate G8D (Celmerowski, 2007).

In order to properly use the potentials of D2 discipline, one should understand the differences between the identification of the problem and the description of the problem. Problem identification should never constitute its description. Identification of a problem at the customer (e.g. the delivery of a defective semi-finished product), so the symptom is reported by the customer, whereas it is the manufacturer's experts task to confirm its occurrence, either based on the customer's description or on the basis of a visual inspection at the customer's site.

In the D2 discipline, in order to describe the problem, only the reported and proven facts should be taken into account. It is unacceptable to hypothesize or speculate about a symptom and the reasons for its occurrence. The correct determination of the problem cause(s) enables a thoroughly performed problem description, while the exact determination of the actual symptom is (often) possible only when visiting the client. 
When the symptom has been confirmed and all the necessary symptom data has been collected, experts may clearly indicate the problem or problems that cause the symptom. A problem, that occurred at the manufacturer can often be identified only after a detailed description of the problem, because this description can guide experts to the source of defective items.

In order to properly perform the description of the problem and identify its source, it is worth using the flowchart constituting the algorithm of conduct in discipline D2 (Fig.1).

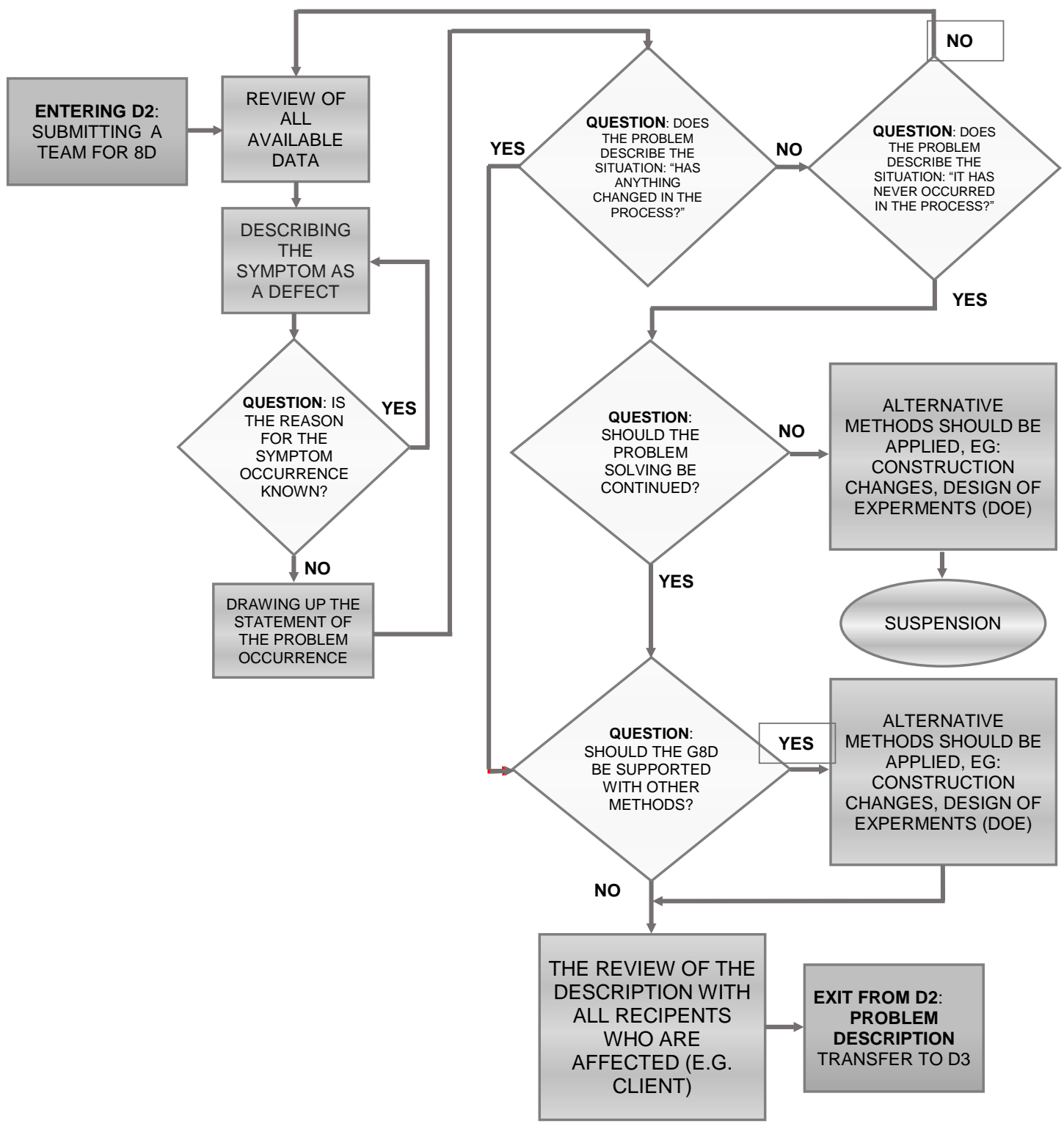

Fig. 1. Algorithm of conduct in discipline D2 - flowchart [elaboration based on (Global 8 D solving workbook, 2018)]

As can be seen in Figure 1, discipline D2 of the G8D method starts with the transition from discipline D1, where a group of specialists was appointed, with a selected Champion and a Leader. They are specialists with the knowledge necessary to solve the problem and to implement corrective actions recommended by the group. 
While preparing the problem description, specialists should use the problem description provided by the client or the description provided by employees who have inspected defective products delivered to the customer (at the customer's site).

The G8D group should also use other information - archival - owned by the company, such as other G8D reports, repair and service reports relating a similar problem. Such reports can turn out to be valuable information that speeds up the analysis and clears defects from the production process.

If the cause of the symptom described as a defect is unknown, a problem statement is made and the procedure follows according to the algorithm.

In the further part of the problem description, the G8D group has to analyze the whole process leading to the occurrence of the defective product in terms of any arising changes. If the answer is positive (changes are found), a decision should be made as to whether the group's activities in G8D will be sufficient or require additional methods to speed up the solution of the problem. Such a method may involve, for example, introducing some structural changes to the product. If, on the other hand, it is determined that the process has not changed and the situation has never occurred before (no such symptom has ever been reported), then the Champion's task is to decide whether the process of searching for the solution to the problem should be continued. If not, then alternative methods are recommended. If yes, then the G8D should be supported with other methods, i.e. the ones discussed above.

If, in the analysed case, the supported of the G8D with other methods is not necessary, a final description of the problem is made and analysed with all recipients who reported the symptom (they feel the consequences of the defective product).

The effect of the G8D team of experts in the discipline D2 is to complete the G8D report in points: Problem Statement and Problem Description.

Adherence to the algorithm of conduct presented in Figure 1 during problem description will allow either to obtain a reliable description of the symptom or to make a decision whether to continue the G8D or suspend further actions.

In each disciplines of the G8D method, various tools are used in the quality management in an enterprises. In D2 discipline, the following tools may be useful (Celmerowski 2007; Ramachandran et all, 2013):

- 5 x Why,

- Ishikawa diagram,

- Pareto diagram,

- diagram of the course of the process,

- control chards,

- SPC techniquesn

- FMEA,

- PFMEA (Banduka, Tadic, et al., 2018.).

In discipline D2, apart from the tools listed above, also data contained in the reports on stated defects are used. An important source of information for the G8D group members are so-called interviews with area leaders or operators.

The use of the aforementioned tools allows for a more accurate and quick implementation of an accurate problem description and enables to indicate the problem source. 


\section{APPLICATION OF D2 DISCIPLINE ALGORITHM FOR A CASE OF A MISSING NUT}

The problem reported by the customer concerned the lack of the M8x16 nut, which should have been welded together with the workpiece sheet at the contractor. The semi-finished product in this form was to be delivered to the customer. This defect was detected at the customer during the assembly of the finished product.

The duty of the quality control department in the company was to check the legitimacy of the customer complaint based on the technical documentation (discipline D1).

The inspection showed the legitimacy of the complaint, and the constructional drawing showed the nut which should have been welded (a projection welding method) to the drawpiece (a steel sheet the semi-finished product was made of). The customer reported a reasonable complaint for about 1500 items of the defective semi-finished product. After accepting the complaint, the company also checked the ready-made products ready for shipping and it turned out that about 1000 items of the defective product had been manufactured.

A visual inspection of product NOK at the customer's site as well as additional activities at the producer's site were required, such as checking the results of the connection control or verifying the strength of the connection. There were two possible problems causing the symptom, such as insufficient weld strength or skipping the welding process.

Using the Ishikawa diagram (the so-called cause-and-effect diagram) for the projection welding of the nut, a list of problems that could cause the symptom felt by the client was drawn up. The symptom was defined as: a missing M8x16 nut and the lack of any possibility of assembling the element to the remaining elements to manufacture a finished product.

The Ishikawa diagram in discipline D2 for the complaint under consideration is shown in Figure 2.

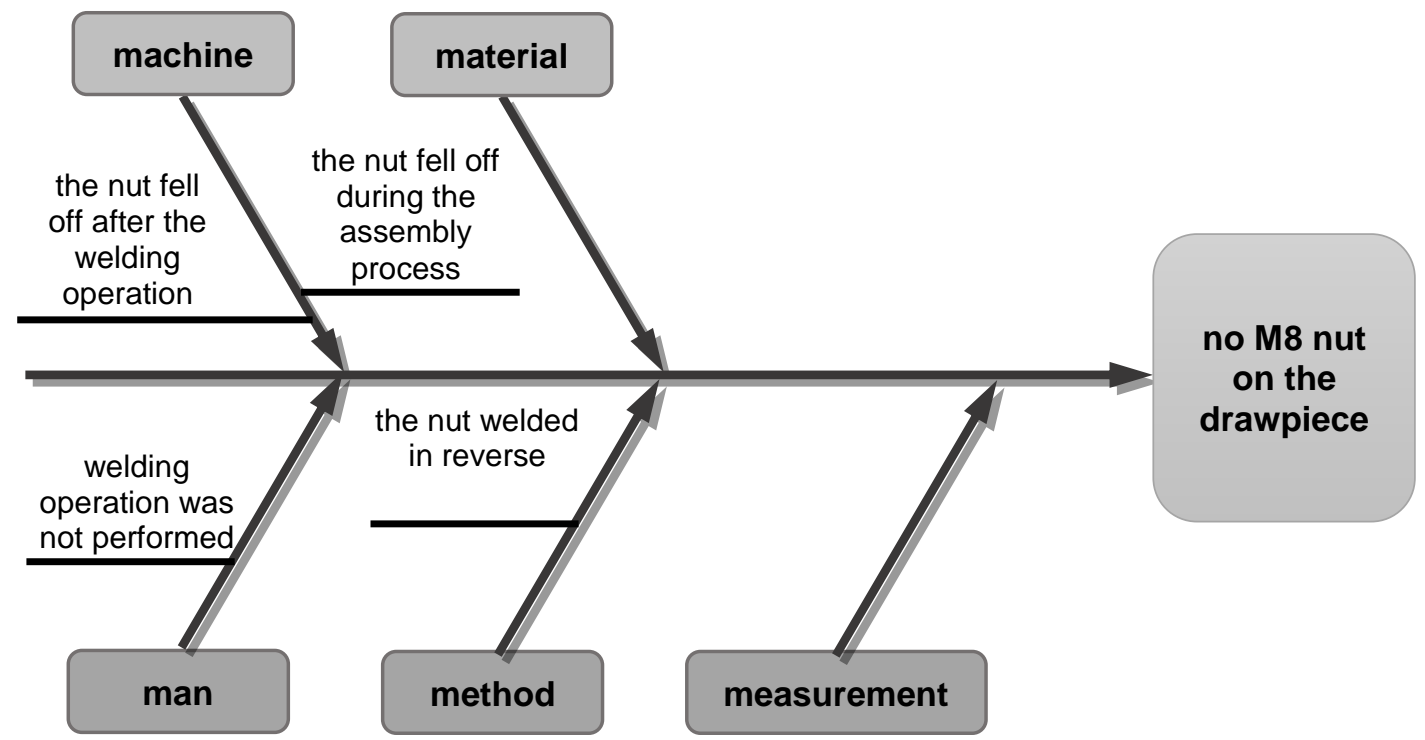

Fig. 2. Ishikawa diagram for the description of the problem of a missing nut - Discipline D2

The faulty detail NOK was confronted with every possible problem. The following potential problems were identified (Figure 2):

- the nut fell off after welding, 
- the nut fell off at the customer's site,

- the nut was welded in reverse,

- no nut.

Due to the lack of welding marks on the element (no fumes characteristic of the welding process - fig. 3), the potential problem "nut fell off after welding" was rejected.

a)

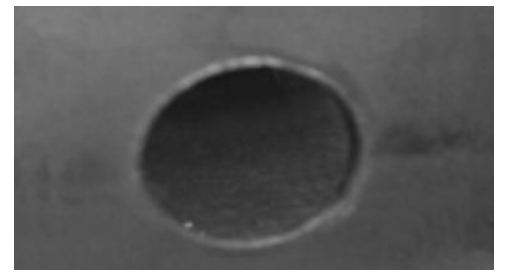

b)

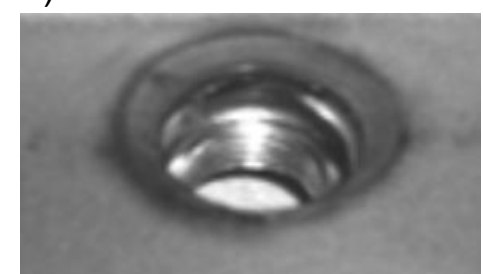

Fig. 3. Comparison of drawpieces: a) without traces of welding, b) welded correctly

Another potential problem: "the nut fell off while the assembly process at the customer's site" was also rejected because the customer did not report such a problem.

The probable problem: "the nut was welded backwards", was also rejected, because firstly, as stated earlier, on the drawpiece to which the nut should be welded there were no visible burn marks, and secondly, the analysis of the feeder feeding the nuts to the welding station did not show any problems.

The reason for "no nut", i.e. a missing nut on the component to be welded, is suggested by: the lack of any traces of welding on the drawpiece and the correct results of the strength tests carried out on the nut-extrusion connection (the post welding control).

The carried out analysis concluded that an incomplete product was delivered to the customer.

Discipline D2 allowed to get a description of the problem that caused the symptom at the client's. The description of the problem is as follows: "the operation of projection welding of M8x16 nut was omitted".

\section{CONCLUSION}

The correct recognition of a customer's problem arising on the supplier's site requires the use of quality management methods and tools. The D2 discipline of the G8D method presented here is an example in which properly used tools and the conduct according to the algorithm proposed in the work allow to determine the type of defect and to obtain an accurate description of the problem. Thanks to this description, the group of employees of the supplier, constituting the G8D team knows which stage of the manufacturing process should be inspected to look for errors leading to defective products being delivered to the customer, and can clearly determine whether the product was damaged at the customer's or the manufacturer's site.

The presented example of the analysis of the selection of the correct problem description shows how important it is to indicate the real problem, taking into account several probable problems. It was important to analyze the complaint and to talk to the client, as well as to inspect the correctly manufactured item and to compare it against the defective item. The correct selection of one of the possible options for the reason of a symptom occurrence at the client's site required a multi-directional 
approach, starting from the analysis of reports on the quality of connections to the analysis of defective elements produced by the manufacturer and which had not yet been sent to the customer.

The analysed case did not require the use of additional quality management tools, and the Ishikawa diagram proved to be sufficient and allowed to indicate the correct description of the problem. However, the use of just one tool is often insufficient to indicate a description of the problem. The members of the G8D group decide what tools to use in the D2 discipline.

\section{REFERENCES}

Allur, E., Heras-Saizarbitoria, I., Boiral, O., Testa, F., 2018. Quality and Environmental Management linkage: A review of the literature. Sustainability, Switzerland, 10(11),4311.

Babica, M., Pająk, E., 2006. Koncepcja metody eliminacji niezgodności w procesach produkcyjnych. Zeszyty Naukowe Politechniki Poznańskiej, 3, 5-15.

Banduka, N., Tadic, D., Macuzic, I, et al., 2018. Extended process failure mode and effect analysis (PFMEA) for the automotive industry: The FSQC-PFMEA. Advances In Production Engineering \& Management, 13, 2, 206-215.

Borcz, A., 2003. Globalne wytyczne zarządzania jakością dla dostawców przemysłu motoryzacyjnego (ISO/TS 16949:2002) na tle sytuacji w branży, Problemy Jakości, 3, $12-14$.

Celmerowski, Z., 2007. Metoda Global 8D. Kraków: TQM soft.

Company reserved materials., 2011.

Company reserved materials., 2012.

Czarski, A., 2010. Statystyczne Sterowanie Procesem - Szkolenie Podstawowe. Kraków: TQM soft.

Global 8D solving workbook, 2018., Results People developing people, Essex

http://cdn2.hubspot.net/hub/170850/file-18472412-pdf/docs/global_8d_workbook.pdf (access 1 November 2018).

Grecu, I., Belu, N., Misztal, A.,2015 Increasing customer satisfaction through the application of the $8 d$ methodology. Management - the key driver for creating value Book Series: International Conference of Management and Industrial Engineering, 488-495.

Harmol, A., Mantura, W., 2002. Zarządzanie jakością teoria i praktyka, third ed. PWN Warszawa-Poznań, Poland.

Hamrol, A., 2012. Zarządzanie jakością z przykładami. PWN, Warszawa, Poland

Ishikawa, K., 1976. Guide to Quality Control. Asian Productivity Organization, Tokyo, Japan

ISO., 2015. Quality Management Principles. Geneva: The International Organization for Standardization, Available online:

https://www.iso.org/files/live/sites/isoorg/files/archive/pdf/en/pub100080.pdf (accessed on 1 November 2018).

Majerník, M., Štofová, L., Bosák, M., Szaryszová, P. , 2016. Process innovations and quality measurement in automotive manufacturing. Production Management and Engineering Sciences - Scientific Publication of the International Conference on Engineering Science and Production Management, ESPM 2015, 179-184. 
Nagi, A., Altarazi, S. 2017. Integration of Value Stream Map and Strategic Layout Planning into DMAIC Approach to Improve Carpeting Process. Journal Of Industrial Engineering And Management-JIEM, 10, 1, 74-97.

Ramachandran, T., Prakash, R., Karthik, R., Valappa, Kumar S., 2013. An application of g8D methodology as a problem solving tool in a manufacturing firm. International Conference of Sustainable Manufacturing and Operations Management ISOM. Conference Materials, Gyandhara International, 331-335

Rambaud, L., 2006. 8D Structured Problem Solving: A Guide to Creating High Quality $8 D$ Reports. PHRED Solutions.

Sarkar, S., Rajagopalan, B., 2018. Consumer safety complaints and organizational learning: evidence from the automotive industry. International Journal of Quality and Reliability Management, 35, 10, 2094-2118.

Savino, M.M., Mazza, A. , 2016. Assessing product sustainability measurement within quality management systems: $A$ case study in automotive industry. International Journal of Productivity and Quality Management 18, 2-3, 258-278.

Tague, N., R., 2004. Seven Basic Quality Tools. American Society for Quality: Milwaukee, Wisconsin, USA.

Wesołowska E., Ż. J. (2006). Sterowanie jakością w procesie montażu - uwagi ogólne. Warszawa: Technologia i Automatyzacja Montażu Nr 1.

Xu, Z.; Dang, Y.; Munro, P., 2018. Knowledge-driven intelligent quality problemsolving system in the automotive industry. Advanced Engineering Informatics, 38, 441-457.

Zymonik, Z., Hamrol, A., Grudowski, P. 2013. Zarządzanie jakością i bezpieczeństwem. PWE, Warszawa 